\title{
Using a geographic information system to identify the number and location of new health centres needed in the city of Kermanshah, Islamic Republic of Iran
}

\author{
Sohyla Reshadat, ${ }^{1}$ Shahram Saeidi ${ }^{1}$ and Alireza Zangeneh ${ }^{1}$
}

${ }^{1}$ Social Development and Health Promotion Research Center, Health Institute, Kermanshah University of Medical Sciences, Kermanshah, Islamic Republic of Iran. (Correspondence to: Shahram Saeidi: SaediShahram@yahoo.com).

\begin{abstract}
Background: Inappropriate distribution of health centres can increase inequities in health care. A geographic information system (GIS) is a useful tool to help plan, monitor and evaluate health systems by analysing and visualizing geospatial data.

Aims: This study aimed to propose an optimal model for establishing new health centres in the city of Kermanshah, Islamic Republic of Iran using GIS.

Methods: In this descriptive analytical study, the number and location of health centres and people's access to them across Kermanshah were evaluated using the GIS system, ArcGIS 10.3, for the years 1997, 2007 and 2012. To determine the best locations for establishing health centres, five principles were considered: access, distance, service delivery radius, proximity to areas of compatible and incompatible land-use, and population density.

Results: In spite of an increase in the number of health centres in Kermanshah between 1997 and 2012, the population without access to such centres also increased, and this varied by age group. Based on the final map of all the land in Kermanshah, $6 \%$ of the land was considered unsuitable or very unsuitable, $16 \%$ medium suitability, and $78 \%$ good or very good for the location of health centres in Kermanshah city.

Conclusion: The spatial distribution of health centres (in terms of the radius of access) and compatibility of the land-use were not properly considered over the 15 -year period. To provide health coverage for the current population in the city of Kermanshah, 13 new health centres are needed in suitable locations.

Keywords: health centres, access, geographic information system, Islamic Republic of Iran

Citation: Reshadat S; Saeidi Sh; Zangeneh A. Using a geographic information system to identify the number and location of new health centres needed in the city of Kermanshah, Islamic Republic of Iran. East Mediterr Health J. 2020;26(8):888-898. https://doi.org/10.26719/emhj.20.022

Received: 12/12/17; accepted: 25/09/18

Copyright (c) World Health Organization (WHO) 2020. Open Access. Some rights reserved. This work is available under the CC BY-NC-SA 3.0 IGO license (https://creativecommons.org/licenses/by-nc-sa/3.o/igo).
\end{abstract}

\section{Introduction}

Over the past 50 years, urban populations have risen but the services provided have not been expanded enough to meet the needs of the people. This has led to undesirable and spatial inequity in urban health services and a waste of human and material resources (1). Today, preventing inequities in the health sector is a main concern of the health policy-makers, especially in developing countries (2). However, a lack of financial and human resources and the growing complexity of health dimensions (physical, mental, emotional, spiritual, and social) are challenges for health policy-makers (3).

Health care services provide health care, maintain and promote health, and restore health at times of illness (4). One of the factors that can both cause inefficiency in the delivery of health services and increase inequality in health services is the inappropriate distribution of health centres (2). The theory of healthy and ecological cities (5) promotes good access to health centres and the placement of urban services at consistent and optimal distances. Factors that can support the proper distribution of health services include good and transparent management, and the required knowledge and tools (6). Managers are important because they are responsible for planning, organizing, directing, innovating, motivating, coordinating and budgeting health services.

Today, the technological developments in the field of health information (7) have increased the importance of using new tools in health management, such as the geographic information systems (GIS) (8,9). GIS is a valuable tool to help ensure that vulnerable and deprived populations have access to primary health care services (10) and hospitals (11). GIS can also be used to plan, monitor and evaluate health systems by gathering, storing, processing, analysing and visualizing geospatial data (3,10-16). Thus, GIS can help reduce inequalities in the distribution of services and identify inequalities in groups, sectors and urban areas.

As mentioned above, identifying and ranking the criteria of a desirable model for location of health centres are important in health services management. Kermanshah is one of the most deprived (17) and underdeveloped (18) provinces of the Islamic Republic of Iran in terms of access to health services. Moreover, Kermanshah has faced many health challenges, including 
high rates of disease such as gastrointestinal cancer and AIDS $(19,20)$ and inequity in access to health centres (2).

The United Nations Sustainable Development Goals aim to ensure healthy lives and promote well-being for all at all ages, reduce inequality, and support sustainable cities and communities (21). In view of these goals and the above-mentioned situation in Kermanshah, allocating resources and health centres in this area is a priority. We therefore aimed to develop an optimal model for establishing new health centres in Kermanshah city using GIS with the aim of supporting our health managers and policy-makers on this issue.

\section{Methods}

This descriptive, analytical study was done over a 15-year period (1993-2012). The number of health centres was our target. People's access to these centres and land-use compatibility status across Kermanshah city were evaluated using ArcGIS 10.3, and its index overlay model and network analyzer (22). Land-use compatibility describes an existing or committed land use or activity that can co-exist with neighbouring use(s)/activity(ies), without either creating or experiencing off-site adverse effects. In the first step we used the ArcGIS intersect and symmetrical difference tools. In this study, the effective layers for locating health centres include proximity to green space $\left(\mathrm{C}_{1}\right)$, proximity to the centre of the neighbourhood $\left(C_{2}\right)$, proximity to fire-fighting services $\left(C_{3}\right)$, proximity to communication networks $\left(\mathrm{C}_{4}\right)$, proximity to population density $\left(\mathrm{C}_{5}\right)$, proximity to residential areas (C6), the slope of the land $(\mathrm{C} 7)$, distance from existing health centres (C8), distance from industrial workshops (C9), distance from urban facilities (C10), distance from places of education (C11), distance from cultural services ( $\left.\mathrm{C}_{12}\right)$, and distance from sports facilities (C13).

In the second step, the proposed map of suitable locations for establishing health centres was extracted using the index overlay model, ArcGIS network analyzer, the fuzzy analytic hierarchy process (AHP) (fuzzy AHP SoLver software, 2015) and GIS. Moreover, to determine the best locations for establishing health centres, five principles were considered (23).

- Access principle: One of the main criteria in locating such critical centres is easy access. In other words, easy access denotes the ability of urban residents to have the access to health centres they wish.

- Distance principle: Use of the distance principle in locating centres is based on the sphere of influence, that is, the standard range covered by each of the health centres.

- Service radius: This is the radius of each of the health centres in terms of delivering services and its distance from the radius of other centres. For example, the standard coverage is a radius of $750 \mathrm{~m}$ which may become shorter because of overlap with other centres.

Proximity principle (compatibility and incompatibility): The presence of some land-use, such as industrial centres in the vicinity of and adjacent to health centres, is known as incompatible land-use, which reduces the efficiency of these health centres. In this regard, we classified land-use into two categories, compatible and incompatible land-use. Items C8 to $\mathrm{C}_{13}$ were considered incompatible land-use. This is because this land-use causes problems such as crowding, noise pollution and atmospheric pollution, and avoiding noise and environmental pollution are among the most important considerations when locating health centres. C7 was considered both compatible and incompatible, and the other items ( $\mathrm{C}_{1}$ to $\mathrm{C} 6$ ) were considered compatible land-use (24).

Population criterion: This is one of the main factors in the establishment of health centres. In other words, there should be more health centres in areas with higher population densities.

We marked the health centres based on statistical blocks of Kermanshah in the environment of ArcGIS maps, and then the urban roads were created. The urban communication network and health centres in Kermanshah city were extracted using the ArcGIS network analyzer. The topology and spatial relationships between the roads were developed in ArcGIS catalog, and the rules and restrictions were imposed through the ArcGIS network analyzer.

In the third step, given that normal walking speed ranges between 0.75 and $1.25 \mathrm{~m} / \mathrm{s}$ (24) and the standard $750 \mathrm{~m}$ catchment radius for health centres (25), a person's speed was set at $1 \mathrm{~m} / \mathrm{s}$. In addition, a walking time of 12.5 minutes was set for the distance of each person's house from the nearest health centre. Then, using the ArcGIS network analyzer, some limits were considered for areas with health centres in terms of people's access to these areas in real time through real roads. The abovementioned items, including the access principle, the distance principle and the service radius, were considered in this step.

In the fourth step (the proximity principle), a minimum distance of $1000 \mathrm{~m}$ was considered (26), and the number of people with and without access to health centres was calculated based on age and gender, and also the area of compatible and incompatible land-use within a radius of $1 \mathrm{~km}$. The ArcGIS intersect and symmetrical difference tools were used for these calculations. The information of layers in terms of compatible and incompatible land-use were as follows.

Incompatible layers: These layers include industrial workshops, urban facilities, educational, cultural, sports facilities, and health centres. The appropriate distance from these land-uses should be considered in locating health centres because of challenges such as air and noise pollution for health centres as well as the optimal and equitable access to health centres and their appropriate distribution in cities. Therefore, the further these landuses are from the health centres, the higher the score (a score of 10 being highest) would be and vice versa. In this model, a distance of $0-100 \mathrm{~m}$ from the incompatible 
land-use has the lowest score (a score of 1), and a distance of more than $750 \mathrm{~m}$ has the highest score (a score of 10). The minimum distance of health centres from the incompatible land-use is $1000 \mathrm{~m}$, and this value was considered as the base analysis of the land-use.

Compatible layers: These include residential areas, green spaces, fire-fighting services, population density, centre of the neighbourhood and communication networks. The shorter the distance of these land-uses from the health centres, the higher the score would be and vice versa. In this regard, quick and timely access to health centres is seen as one of the basic needs of households. Accordingly, the proximity and access to urban streets is one of the best options for the location of health centres. Thus, if the distance from the main streets is reduced, the score will be higher and vice versa. Moreover, proximity to the centre of the neighbourhood is another factor that should be considered for residents, and equitable distribution of health centres is one of the objectives and criteria of locating such land-use. Therefore, the shorter the distance of health centres from the centre of the neighbourhood, the higher the score will be and vice versa.

It should be noted that areas with a slope of the land value of $0-5 \%$ will have a higher score (the compatible section) and areas with a slope of $20-100 \%$ will have a lower score (the incompatible section) (26-30).

In the fifth step, to examine the population criterion, a population density of more than 150 population $/ \mathrm{km}^{2}$ was considered (31).

Modelling is important in geographical studies and the model of overlapping indexes is one of the most important models (32). In this modelling, units in each information layer are given weights based on their capability, in addition to the weights of the information layers, and the input maps are given weights according to their importance (33). The simplest type of index weighting is when maps are binary (consisting of pixels that can have one of only two colours, usually black and white) (34) and each map has a single weighting factor.

We used AHP to assign weights to criteria (35). This method is based on pairwise comparisons and determining the priority of elements over other criteria. It is used to solve multicriteria problems and prioritization of alternatives using the intended criteria (36). In our modelling, the final map was extracted for the decisionmaking of health managers by reviewing the literature and interviews with experts in connection with the significance of each layer and their combinations using the fuzzy AHP (23,37).

Figure i Study processes

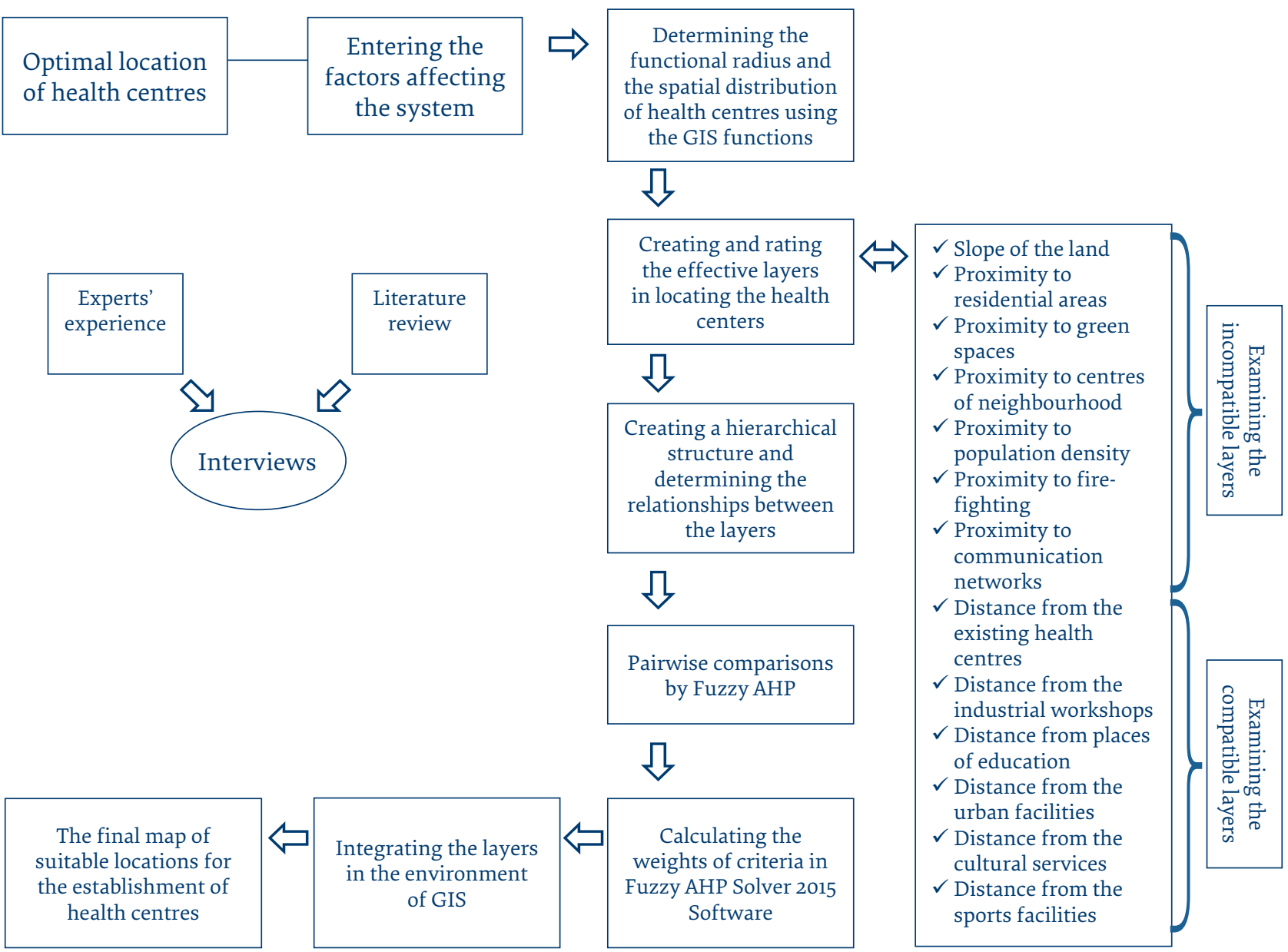


The research framework and processes of our study are shown in Figure 1.

\section{Results}

The distribution of health centres in Kermanshah city was not uniform. Given the assigned walking time of 12.5 minutes for each person from his/her home to a health centre during the three periods under study (1997, 2007 and 2012), the percentage of the population with access to health centres fell while the percentage of the population without access increased.

The population of Kermanshah city was 693157 in 1997, 794863 in 2007 and 851405 in 2012. The deprived population increased from $47.28 \%$ in 1997 to $55.65 \%$ in 2007 and $58.39 \%$ in 2012 , while the number of health centres increased from 29 in 2007 to 33 in 2007 and to 34 in 2012 based on ArcGIS network analyzer (Figure 2). In 1997, 38.57\% of those aged 0-14 years did not have access to health centres compared with $22.97 \%$ in 2007 and $20.44 \%$ in 2012 . As regards older ages, $56.62 \%$ of those aged 15-65 years did not have access to health centres in 1997 compared with $70.50 \%$ in 2007 and $74.76 \%$ in 2012 . However, $4.81 \%$ of the age group 65 years and older did not have access to health centres in 1997 as opposed to $6.53 \%$ in 2007 and $4.79 \%$ in 2012 (Table 1). In 2012, 354236 people (41.61\%) had access to health centres, of which 114859 people $(32.42 \%)$ had access to two or three health centres.

Kermanshah city had eight fire-fighting services in the compatible layers, of which two were out of the range (radius of $1 \mathrm{~km}$ ). With regard to proximity to the centres of neighbourhoods, we identified 121 centres of neighbourhoods, of which 40 (33\%) were out of the range (radius of $1 \mathrm{~km}$ ). This finding suggests that many areas have been deprived of the services provided by these centres. Moreover, all health centres were constructed along the street. In other words, the layer of proximity to streets had been considered in the establishment of health centres. The slope of the land fit into both groups: compatible (areas with a slope of $0-5 \%$ will have a higher score) and incompatible (areas with a slope of $20-100 \%$ will have a lower score). According to our findings, most of the central areas of Kermanshah city had a 5\% slope and the surrounding areas had slopes ranging between $20 \%$ and $100 \%$. Moreover, $92.42 \%$ of compatible land-use and $84.79 \%$ of incompatible use were within the range covered by health centres (radius of $1 \mathrm{~km}$ ) (Table 2 and Figure 3).

In Figure 4, the information layers were scored in both compatible and incompatible groups. We created the hierarchical structure, determined the relationships between layers $\left(\mathrm{C}_{1}-\mathrm{C}_{13}\right)$, and made pairwise comparisons by reviewing literature and interviews with experts (2628). Additionally, the weights of the information layers were determined by fuzzy AHP (fuzzy (AHP SoLver, 2015) (Table 3). The layers and their weights are shown in Table 4.

After ranking and combining layers with overlapping indexes in GIS software, the output layer was developed, whereby suitable lands were identified for establishing health centres. Land with higher scores had better conditions for the establishment of health centres. The final map indicated five belts for new sites for health centre as in Kermanshah city (Figure 5). The outer areas, shown in red, with a total area of $3015988 \mathrm{~m} 2$ had the lowest value (very unsuitable sites); these areas are located in the northern and southern parts of Kermanshah city. The orange belts with an area of $3684334 \mathrm{~m} 2$ and the yellow belts with an area of $18590936 \mathrm{~m} 2$ were ranked

Figure 2 Functional radius and spatial distribution of health centres and areas with and without health centre coverage in 1997, 2007 and 2012
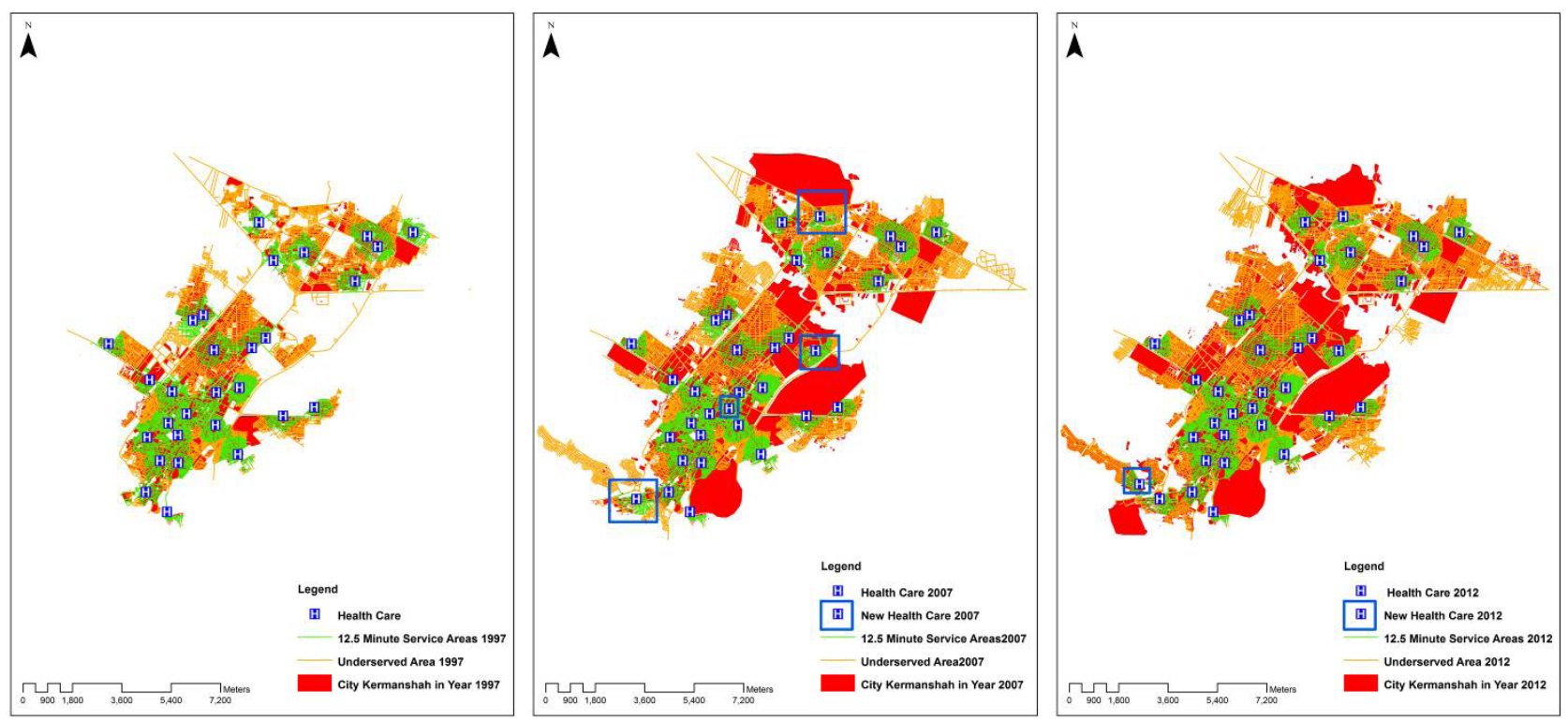


\begin{tabular}{|c|c|c|c|c|c|c|c|c|}
\hline \multirow[t]{3}{*}{ Year/Sex } & \multicolumn{8}{|c|}{ Age groups (years) } \\
\hline & \multicolumn{2}{|c|}{ Total } & \multicolumn{2}{|c|}{$0-14$} & \multicolumn{2}{|c|}{$15-65$} & \multicolumn{2}{|c|}{$\geq 65$} \\
\hline & No. & $\%$ & No. & $\%$ & No. & $\%$ & $\mathbf{N}$ & $\%$ \\
\hline \multicolumn{9}{|l|}{1997} \\
\hline Female & 160959 & 49.12 & 61580 & 38.26 & 92310 & 57.35 & 7069 & 4.39 \\
\hline Male & 166753 & 50.88 & 64820 & 38.87 & 93244 & 55.92 & 8689 & 5.21 \\
\hline Total & 327712 & 100 & 126400 & 38.57 & 185554 & 56.62 & 15758 & 4.81 \\
\hline \multicolumn{9}{|l|}{2007} \\
\hline Female & 215101 & 48.62 & 50418 & 23.44 & 154551 & 71.85 & 10132 & 4.71 \\
\hline Male & 227286 & 51.38 & 51201 & 22.53 & 157339 & 69.23 & 18746 & 8.25 \\
\hline Total & 442387 & 100 & 101619 & 22.97 & 311890 & 70.50 & 28878 & 6.53 \\
\hline \multicolumn{9}{|l|}{2012} \\
\hline Female & 247769 & 49.83 & 49038 & 19.79 & 186908 & 75.44 & 11823 & 4.77 \\
\hline Male & 249400 & 50.17 & 52591 & 21.09 & 184800 & 74.10 & 12009 & 4.82 \\
\hline Total & 497169 & 100 & 101629 & 20.44 & 371708 & 74.76 & 23832 & 4.79 \\
\hline
\end{tabular}

unsuitable and medium suitability sites, respectively. The turquoise belts with an area of $35423271 \mathrm{~m} 2$ and the blue belts with an area of $51641924 \mathrm{~m} 2$ were ranked good and very good sites, respectively. In general, given the existing conditions and based on our data, we suggest 13 new health centres should be built in Kermanshah city (Figure 5).

\section{Discussion}

Our study shows that even with an increase in the number of health centres in Kermanshah city, the percentage of the population without access to health centres was on the rise, $47.28 \%$ in $1997,55.65 \%$ in 2007 and $58.39 \%$ in 2012. Kermanshah city has increased in population from 693000 in 1997 to 851000 in 2012. The inappropriate spatial distribution of health centres is another challenge that Kermanshah city has, which is due reduced optimal access to health centres and the irrational accumulation of these centres in certain places. Some of the consequences of this issue are the lack of equal opportunity for people, injustice (2), negative changes in the ecological, human and natural structure of healthy cities, and inefficiency of the urban health management system in using funds (25).

Health centres were not distributed appropriately across Kermanshah city. Over the period 1997-2007, four new health centres were established, three of which were appropriately located. However, one centre was established in a part of the city that was already covered by other centres and there was no need for it. Similarly, from 2007 to 2012, a new health centre was established which overlapped with a neighbouring centre. Based on our data, the interference of the function radius was very

Table 2 Areas of the land use within and outside the range covered by the health centres (radius of $1 \mathrm{~km}$ ) in Kermanshah city

\begin{tabular}{|c|c|c|c|c|c|}
\hline \multirow[t]{2}{*}{ Type of land use } & \multirow[t]{2}{*}{ Total area } & \multicolumn{2}{|c|}{$\begin{array}{l}\text { Land use within the range } \\
\text { covered by health centres }\end{array}$} & \multicolumn{2}{|c|}{$\begin{array}{l}\text { Land use outside the range } \\
\text { covered by health centres }\end{array}$} \\
\hline & & Area & $\%$ & Area & $\%$ \\
\hline \multicolumn{6}{|l|}{ Compatible } \\
\hline Residential & 17764003 & 15871617 & 89.35 & 1892386 & 10.65 \\
\hline Green space & 4656665 & 3802101 & 81.65 & 854564 & 18.35 \\
\hline Blocks with high population density & 21020679 & 20474774 & 97.40 & 545905 & 2.60 \\
\hline Total & 43441347 & 40148492 & 92.42 & 3292855 & 7.58 \\
\hline \multicolumn{6}{|l|}{ Incompatible } \\
\hline Industrial workshops & 2162608 & 1676362 & 77.52 & 486246 & 22.48 \\
\hline Educational centres & 2791985 & 2474194 & 88.62 & 317791 & 11.38 \\
\hline Urban facilities & 559975 & 503979 & 90.00 & 55996 & 10 \\
\hline Cultural services & 124581 & 98133 & 78.77 & 26448 & 21.23 \\
\hline Sports facilities & 365020 & 338175 & 92.65 & 26845 & 7.35 \\
\hline Total & 6004169 & 5090843 & 84.79 & 913326 & 15.21 \\
\hline
\end{tabular}




\section{Figure 3 Compatible and incompatible land-use within a} radius of $1 \mathrm{~km}$ of the health centres

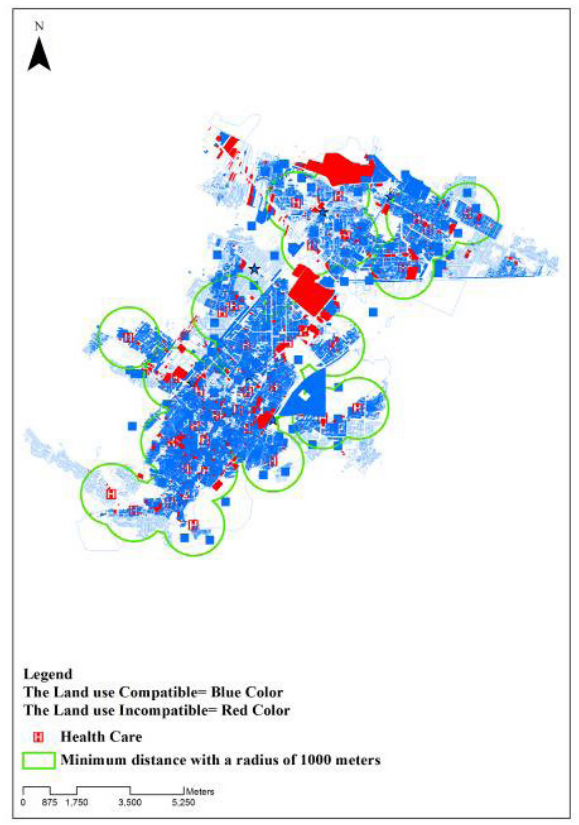

high, so that $32.43 \%$ of people had access to two or three health centres, thereby resulting in a waste of resources in terms of the optimal use of facilities in these health centres. Our findings on the lack of appropriate and uniform access to health centres across Kermanshah city are consistent with the results of other studies $(25,26,29,38-40)$. Based on our results, if more detailed need assessments and planning had been done in Kermanshah city over 1997-2007, it would have been possible for the areas in need of health centres to be better covered instead of establishing new centres in areas already covered. This situation would have resulted in higher productivity, better public satisfaction, less duplication of previous programmes and time-saving compared with the current circumstances. The results of studies in other countries have shown that adopting inappropriate management strategies results in the loss of resources (6).

In addition, our results show that the population without access to health centres in the age group 0-14 years had decreased from $38.57 \%$ to $20.44 \%$. Population growth has decreased in the Islamic Republic of Iran and this decrease may explain the declining trend in the population of children without access to health centres. In those aged 15-65 years, the percentage of the population without access to health centres was on the rise (from $56.62 \%$ in 1997 to $74.76 \%$ in 2012). For the group over 65 years, the percentage without access increased from 1997 to 2007 and then decreased from 2007 to 2012 (from 6.53\% to $4.79 \%$ ). Given the reconstruction and renovation plan in recent years in central areas of Kermanshah city, the number of migrants to the peripheral suburbs has risen. Also, because of the accumulation of health centres and the large population of elderly people in Kermanshah (before migration and renovation/renewal policies), these factors may be a reason for the decline in the population without access to health centres in 2012. In general, this lack of responsiveness to the needs of residents without proper access to health centres and the lack of social justice cause damage in community groups, especially vulnerable groups. In cities such as Kermanshah where ethnic segregation exists between residents of different neighbourhoods $(25,41)$, the accumulation of services in particular places across the city is unjustifiable and disturbs the human, natural and ecological structure of cities.

The analysis of the compatibility and incompatibility of land-use across Kermanshah city showed that about $92 \%$ of the compatible and $85 \%$ of incompatible lands were in the range of $1000 \mathrm{~m}$ from the health centres. The large amount of compatible and incompatible land-use around health centres indicates that these centres were established without planning, which is one of the main reasons for the failure of urban health projects in the country (42).

As for compatible land-use, residential area (89\%), green spaces $(81 \%)$, densely populated blocks (97\%), firefighting services (75\%) and centres of the neighbourhoods $(67 \%)$ were within a radius of $1 \mathrm{~km}$ of the health centres. The presence of such compatible land-use in the vicinity of health centres is an advantage. However, the existence of incompatible land-use (e.g. sports facilities (92\%), urban facilities (90\%), places of education (89\%), cultural services $(78 \%)$ and industrial workshops (77\%) within a radius of $1 \mathrm{~km}$ of the health centres) is a disadvantage. Our finding on the lack of appropriate planning for the distribution of land-use concur with the results of other studies (42). The lack of planning in the urban land-use has led to the wide distribution of incompatible land-use throughout Kermanshah city.

Given that a large proportion of the population did not have proper access to health centres, and this situation was related to the location and insufficient number of health centres, we conclude that 13 new health centres should be established on suitable land across Kermanshah city. The use of GIS software by health managers in their planning and decision-making is recommended. By doing so, health policies and management decisions in Kermanshah city will be enhanced.

Funding: Kermanshah University of Medical Sciences.

Competing interests: None declared. 
Figure 4 Scoring the effective layers by distance for compatible and incompatible groups
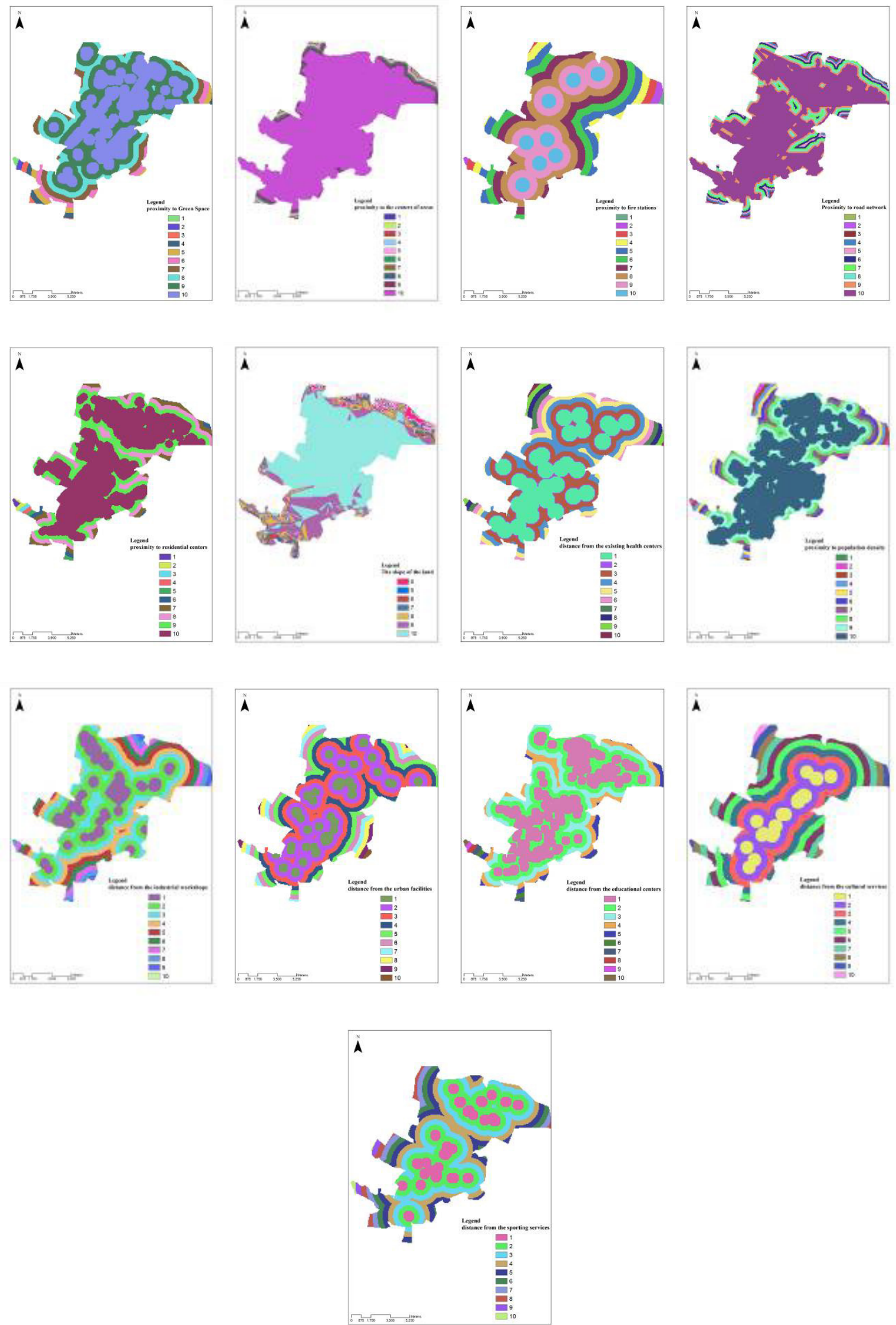


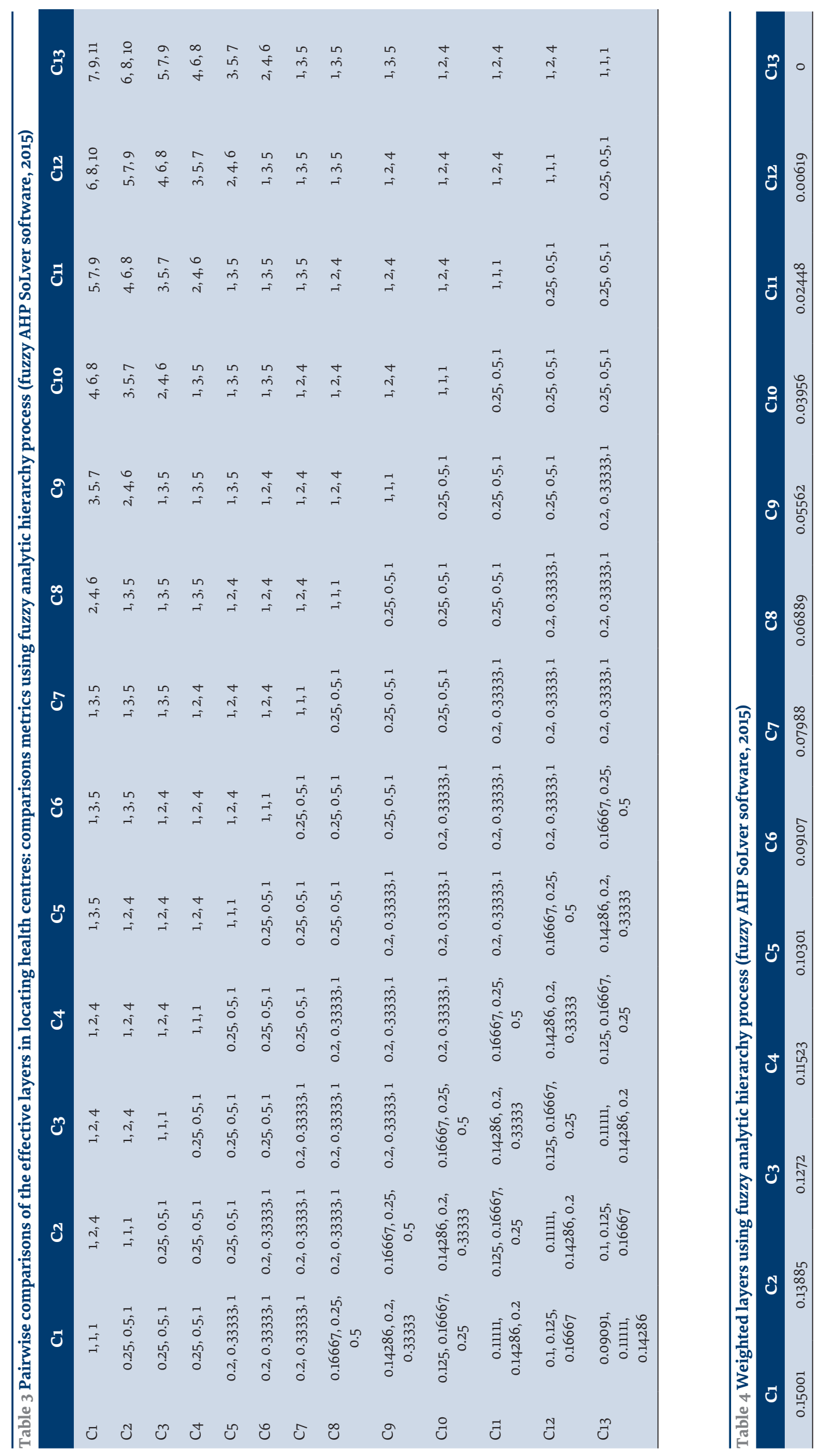



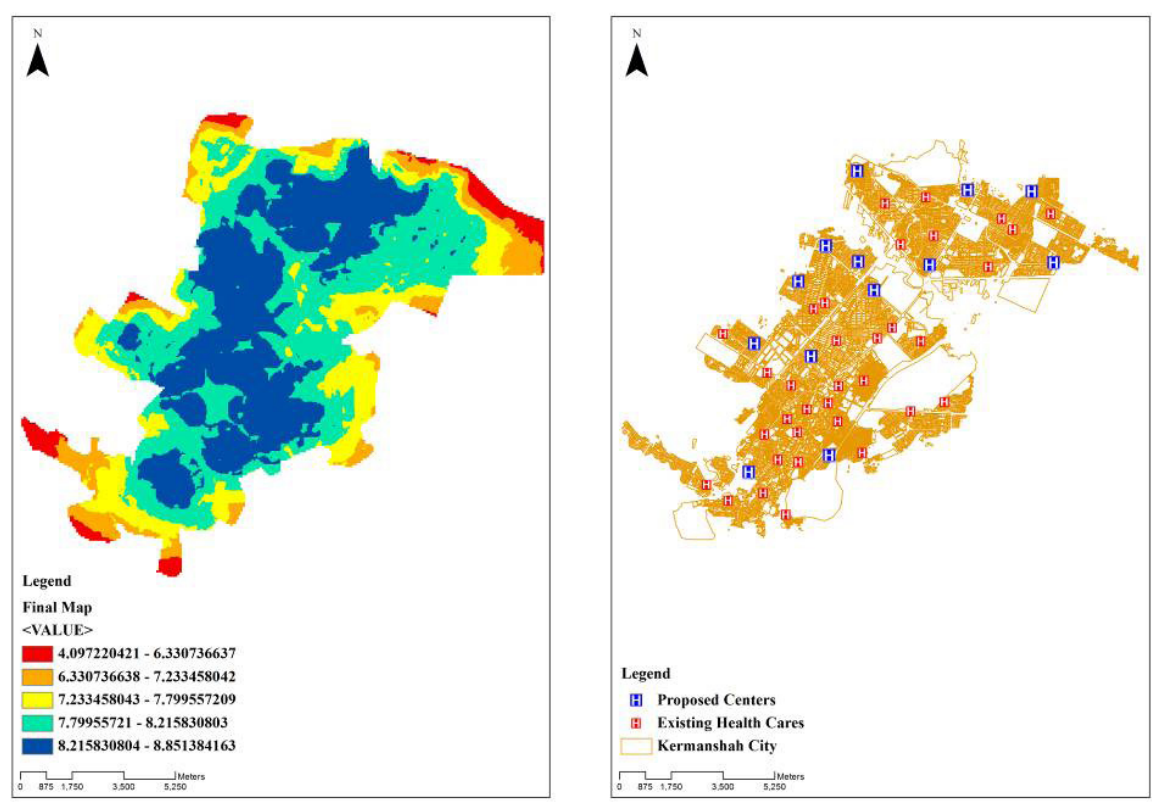

\section{Utilisation d'un système d'information géographique pour déterminer le nombre de nouveaux centres de santé nécessaires dans la ville de Kermanshah, ainsi que leur emplacement (République islamique d'Iran)}

\section{Résumé}

Contexte : Une répartition inappropriée des centres de santé peut aggraver les inégalités en matière de soins de santé. Un système d'information géographique (SIG) est un outil intéressant qui permet de planifier, de surveiller et d'évaluer les systèmes de santé en analysant et en visualisant des données géospatiales.

Objectifs : La présente étude visait à proposer un modèle optimal pour la création de nouveaux centres de santé dans la ville de Kermanshah (République islamique d'Iran) au moyen d'un SIG.

Méthodes : Dans cette étude analytique descriptive, le nombre de centres de santé, leur emplacement et l'accès de la population à ces centres dans l'ensemble de la ville de Kermanshah ont été évalués à l'aide du système d'information géographique ArcGIS 10.3, pour les années 1997, 2007 et 2012. Afin de déterminer les meilleurs emplacements pour établir des centres de santé, cinq principes ont été pris en compte : l'accès, la distance, la portée des services fournis, la proximité de zones d'aménagement compatibles et incompatibles et la densité de population.

Résultats : Malgré l'augmentation du nombre de centres de santé à Kermanshah dans la période comprise entre 1997 et 2012, la population n'ayant pas accès à ces centres s'est également accrue, et ce de manière variable selon les groupes d'âge. Sur la version finale du plan de l'ensemble des terrains de Kermanshah, 6 \% des terrains ont été jugés inadaptés ou très inadaptés, $16 \%$ moyennement adaptés et $78 \%$ bien adaptés ou très adaptés à l'implantation de centres de santé dans la ville.

Conclusion : La distribution spatiale des centres de santé (vue sous l'angle du rayon d'accès) et la compatibilité des terrains n'ont pas été correctement prises en compte sur cette période de 15 ans. Pour assurer la couverture sanitaire de la population actuelle de la ville de Kermanshah, il faudrait créer 13 nouveaux centres de santé à des emplacements appropriés. 


\section{الاستخدام نظام المعلومات الجغر افية لتحديد عدد المر اكز الصحية الجلديدة وموقعها في مدينة كرمنشاه، جمهورية إيران الإسلامية}

سُهيلا رشادات، شهرام سعيدي، علي رضا زنجنه

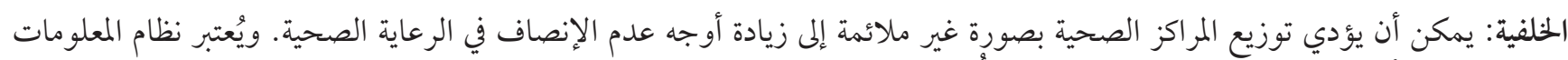

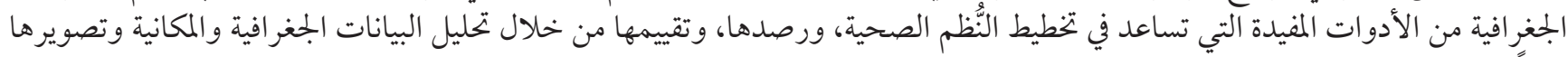

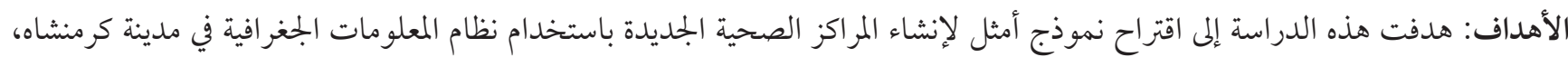
جهورية إيران الإسلامية.

طرق البحث: في هذه الدر اسة التحليلية الوصفية، تم تقيم عدد المراكز الصحية وموقعها وإمكانية وصول الناس إليها في جميع أنحاء كرمنشاه، أفراء

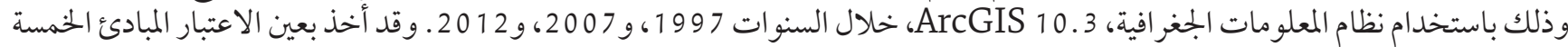

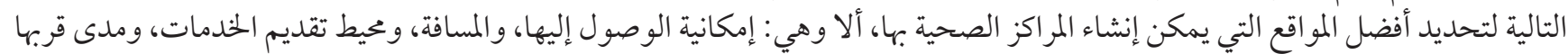

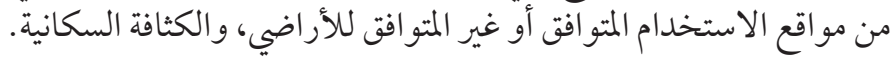

النتائج: على الرغم من زيادة عدد المر اكز الصحية في مدينة كرمنشاه في الفترة بين عامي

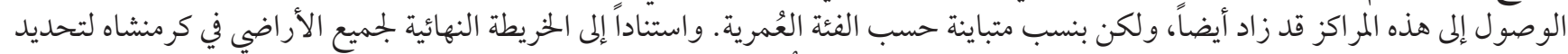

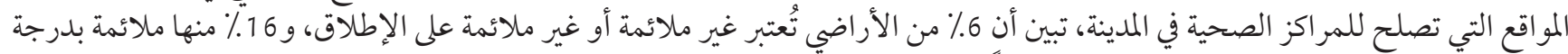

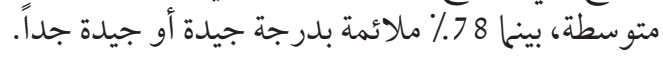

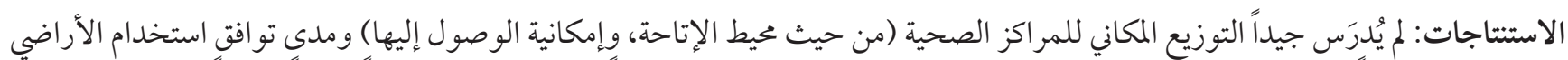

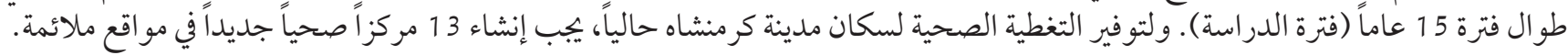

\section{References}

1. Rana MS. Status of water use sanitation and hygienic condition of urban slums: a study on Rupsha Ferighat slum, Khulna. Desalination. 2009;246(1-3):322-8. https://doi.org/10.1016/j.desal.2008.04.052

2. Reshadat S, Saedi S, Zangeneh A, Amooie MR, Karbasi A. [Equity in access to health care using geographic information system: a Kermanshah case study.] J Mazandaran Univ Med Sci. 2014;24(115):134-40 [In Farsi].

3. Abbasi M, Hasoumi M, Mohamadi E, Asadi H. [Analysis of the relationship between distributions of health sector inputs and health outcomes in Iran; using Gini coefficient.] Bioeth J. 2016;4(12):65-79 [In Farsi].

4. Salimi M, Arab M, Akbari F, Zeraati H, Farzianpoor F. [A survey on the status of environmental health management in Qom province hospitals.] J School Public Health and Inst Public Health Res. 2007;5(3):59-66 [In Farsi].

5. Harvey D. The condition of postmodernity: an enquiry into the origins of social change. Oxford: Blackwell Publishers; 1989.

6. Safarzadeh H, Tadayon A, HorMohammadi M. [The evaluation of effects of knowledge management strategy on organizational innovation and performance (a case study in community health centers of north part of Fars province).] Toloo-E-Behdasht. 2012;11(1):76-86 [In Farsi].

7. Barzoki JM, Raeesi A, Isfahani SS, Tavakoli N. Comparative study of structure and activity of health information management association in selected countries, 2008. Health Inf Manag. 2010;7(3):13-27.

8. Schempf AH, Kaufman JS, Messer LC, Mendola P. The neighborhood contribution to black-white perinatal disparities: an example from two north Carolina counties, 1999-2001. Am J Epidemiol. 2011;174(6):744-52. https://doi.org/10.1093/aje/kwr128.

9. Bazemore A, Diller P, Carrozza M. The impact of a clinic move on vulnerable patients with chronic disease: a geographic information systems (GIS) analysis. J Am Board Fam Med. 2010;23(1):128-30. https://doi.org/10.3122/jabfm.2010.01.090103

10. Cinnamon J, Schuurman N, Crooks VA. A method to determine spatial access to specialized palliative care services using GIS. BMC Health Serv Res. 2008;8(1):140-51. https://doi.org/10.1186/472-6963-8-140

11. Graves BA. Access to cardiac interventional services in Alabama and Mississippi: a geographical information system analysis. Perspect Health Inf Manag. 2010;1:7.

12. Photis YN, Manetos P. Geographic information analysis and health infrastructure. Health Sci J. 2007;1(3):55-67.

13. Dulin MF, Ludden TM, Tapp H, Smith HA, de Hernandez BU, Blackwell J, et al. Geographic information systems (GIS) demonstrating primary care needs for a transitioning Hispanic community. J Am Board Fam Med. 2010;23(1):109-20. https://doi. org/10.3122/jabfm.2010.01.090136.

14. Pollack CE, Gidengil C, Mehrotra A. The growth of retail clinics and the medical home: two trends in concert or in conflict? Health Aff. 0105 2010;29(5):998-1003. https://doi.org/10.1377/hlthaff.2010.0089. 
15. Tanser F. Methodology for optimising location of new primary health care facilities in rural communities: a case study in KwaZulu-Natal, South Africa. J Epidemiol Community Health. 2006;60(10):846-50. http://doi.org/10.1136/jech.2005.043265

16. Abbas II, Auta SZ, Na'iya RM. Health care facilities mapping and database creation using GIS in Chikun local government, Kaduna State, Nigeria. Glob J Human Soc Sci Res. 2012;12(10):35-42.

17. Taghvaei M, Shahivandi A. [Spatial distribution of health services in Iranian cities.] Social Welfare Q. 2011;10(39):33-54 [In Farsi].

18. Taharimehrjardi MH, Babaeimeybodi $\mathrm{H}$, Morovatisharifabadi A. Investigation and ranking of Iranian provinces in terms of access to health sector indicators. Health Inf Manag. 2012;9(3):356-69.

19. Reshadat S, Saeidi S, Zangeneh A, Khademi N, Khasi K, Ghasemi S, et al. Spatiotemporal distribution of gastrointestinal tract cancer through GIS over 2007-2012 in Kermanshah-Iran. Asian Pac J Cancer Prev. 2014;16(17):7737-42. https://doi.org/10.7314/ APJCP.2015.16.17.7737

20. Khademi N, Reshadat S, Zangeneh A, Saeidi S, Ghasemi S, RajabiøGilan N, et al. A comparative study of the spatial distribution of HIV prevalence in the metropolis of Kermanshah, Iran, in 1996-2014 using geographical information systems. HIV Med. 2017;18(3):220-4. https://doi.org/10.1111/hiv.12416/

21. Sustainable Development Goals. New York: United Nations Development Programme; 2016; (http://www.undp.org/content/ undp/en/home/sustainable-development-goals.html/, accessed 27 May 2017).

22. Reshadat S, Zangeneh A, Saeidi S, Teimouri R, Yigitcanlar T. Measures of spatial accessibility to health centers: investigating urban and rural disparities in Kermanshah, Iran. J Public Health. 2019;27(4):519-29. https://doi.org/10.1007/s10389-018-0966-9

23. Torabi-Kaveh M, Babazadeh R, Mohammadi S, Zaresefat M. Landfill site selection using combination of GIS and fuzzy AHP, a case study: Iranshahr, Iran. Waste Manag Res. 2016;34(5):438-48. https://doi.org/10.1177/0734242X16633777

24. Ghanbari A, Ghanbari M. Assessing spatial distribution of Tabriz parks by GIS (compared network analysis and buffering). Geogr Environ Plann. 2013;24(2):223-34.

25. Reshadat S, Saedi S, Zangeneh A, Ghasemi S, Gilan N, Karbasi A, et al. Spatial accessibility of the population to urban health centres in Kermanshah, Islamic Republic of Iran: a geographic information systems analysis. East Mediterr Health J. 2015;21(6):38995 .

26. Ahadnejad M, Ghaderi H, Hadian M, Haghighatfard P, Darvishi B, Haghighatfard E, et al. [Location allocation of health care centers using geographical information system: region 11 of Tehran.] J Fasa Univ Med Sci. 2015;4(4):463-74 [In Farsi].

27. Sahraeian Z, Zangiabadi A, Khosravi F. [Spatial analysis and site selection of health medical and hospital centers using (GIS)(case study: Jahrom City).] Geogr Space. 2013;13(43):153-70 [In Farsi].

28. Reshadat S, Saeidi S, Sufi E, Rjabi-Gilan N, Ghasemi R. [Investigating inequalities in access to hospital medical facilities using geographical information system in Kermanshah's Metropolitan area.] J Hosp. 2016;15(2):9-22 [In Farsi].

29. Ebrahimzadeh I, Ahadnezhad M, Ebrahimzadeh AH, Shafiei Y. [Spatial organization and planning of health services by the use of GIS: the case of Zanjan City.] Human Geogr Res Q. 2010;(73):39-58 [In Farsi].

30. Khakpoor B, Purghayoomi H, Ghanbari M. [Location health-therapeutic centers of Nourabad by use analytical hierarchy process in GIS.] Health Inf Manag. 2014;11(2):221-33. http://him.mui.ac.ir/index.php/him/article/view/1082 [In Farsi]

31. Azizi MM. [Urbanism density, urban density principles and criteria set.] Tehran: Tehran University Publications; 2010 [In Farsi].

32. Varesi HR SN, Shahsavani MJ. [Locating sanitary therapeutic centers using geographic information system (GIS) and analytical hierarchy process (AHP) (case study Najaf Abad city).] Health Inf Manag. 2015;11(7):851-64 [In Farsi].

33. Zebardast E. [Application of analytic hierarchy process in urban and regional planning.] Honar-Ha-Ye-Ziba. 2002;4(10):13-21 [In Farsi].

34. Ozdemir A. Using a binary logistic regression method and GIS for evaluating and mapping the groundwater spring potential in the Sultan Mountains (Aksehir, Turkey). J Hydrol. 2011;405(1):123-36. https://doi.org/10.1016/j.jhydrol.2011.05.015

35. Yaghfoori H, Sahrai A, Khalifelo S. [The landuse planning of urban areas and optimal locating with emphasis on health centers: a case study of zone 3 in Zahedan City.] J Hosp. 2014;13(2):9-20 [In Farsi].

36. Tolga E, Demircan ML, Kahraman C. Operating system selection using fuzzy replacement analysis and analytic hierarchy process. Int J Prod Econ. 2005;97(1):89-117. https://doi.org/10.1016/j.ijpe.2004.07.001

37. Tahvili S, Saadatmand M, Bohlin M. Multi-criteria test case prioritization using fuzzy analytic hierarchy process. Paper presented at the Tenth International Conference on Software Engineering Advances, 15-20 November, 2015, Barcelona, Spain.

38. Sharifzadegan M, Mamdohi M. [A P-median-model-based analysis of spatial inequality in accessibility to public health care intended for urban health development in Isfahan City.] Social Welfare Q. 2010;10 (37):265-85 [In Farsi].

39. Hu R, Dong S, Zhao Y, Hu H, Li Z. Assessing potential spatial accessibility of health services in rural China: a case study of Donghai county. Int J Equity Health. 2013;12 (1):1-11. https://doi.org/o.1186/475-9276-12-35/

40. Munoz UH, Källestål C. Geographical accessibility and spatial coverage modeling of the primary health care network in the Western Province of Rwanda. Int J Health Geogr. 2012;11 (1):1-11. https://doi.org/10.1186/1476-072X-11-40

41. Jamshidi A, Jamini D, Jamshidi M, Cheraghi R. Informal settlement, prioritizing current challenges case study: jafar abad district in Kermanshah City. Human Geogr Res Q. 2014;45 (4):221-45.

42. Mshkeni AB, HaselTalab M, M P. [Evaluation of the consistency of land use based on GIS-AHP model in Onsori area of Mashhad.] J Geogr Reg Dev Res. 2014;(20):259-79. https://doi.org/10.22067/geography.v11i20.30793 [In Farsi] 